Share Printer-ready version

\section{Access This Journal at Wiley Online Library}

\section{Oxford Journal of Archaeology}

Vol 31 ( 4 Issues in 2012)

Edited by: Nicholas Purcell, Barry Cunliffe, Helena Hamerow and Chris Gosden

Print ISSN: 0262-5253

Subscription Information

\section{Description}

Covering the whole range of archaeology, from Palaeolithic to medieval times, the Oxford Journal of Archaeology is the premier English language journal of European and Mediterranean archaeology. Publishing four issues a year, it provides topical coverage of current research in Prehistoric, Classical and later European archaeology, with contributions from an international cast of academics and field workers. It encourages debate and is essential reading for anyone studying European archaeology.
Online ISSN: 1468-0092

$\square$ Read Now Online
Read articles online

Subscribe or renew subscriptions

Find Author Guidelines

\section{Permissions}

To reuse content from this title Request Permissions

\section{Related Subjects}

Prehistoric Archaeology Social Archaeology

Archaeological Methods \& Theory

Archaeology Special Topics
Advertising details and more

\section{OXEORD IOURNAL OEARCHAEOLOGY}

Oxford Journal of Archaeology

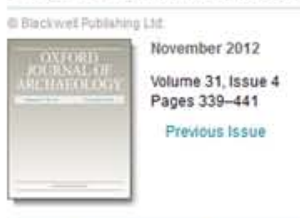

Select All Save to proflie Export citation

Original Articles Jump to -

1. If PERILOUS WATERS: EARLY MARTIME TRADE ALONG THE WESTERN COAST OF THE BLACK SEA (FIFTH MALLEMIUUM BC) (pages 339-365) BLACK SEA (FIFT
MARMA NAWOVA

MARINA NAWOVA Abstract | Full Article (HTML) | POF(1648K) | References | Request Permissions Go here for SIX

If If MEW EVIDENCE FOR IRON AGE BURIAL AMD PROPMITION PRACTICES IM SOUTHERN BRITAIN (pages 367-379)

SOUTHERN BRITANI TRACEY TRACE Abstract | Full Article (MTML) | POF(1216K) | References | Request Permissions Go here for SFX

[1 if THE ASTRONOMICAL ORIENTATION OF THE URBAN PLAN OF ALEXANDRIA (pages 381-389)

Artcle first published online - 9 OCT 2012 /DOt: 10111101468 -0092 201200394 . Abstract | full Article (HTML) | POF(1792K) | References | Request Permissions

Go here for SFX

II If BEYOND THE OPPIDA: POLYFOCAL COMPLEXES AND LATE IRON AGE SOCIETES II SOUTHERU BRITAIN (pages 391-417)

TOM MOORE Abstract | Full Article (HTML) | POF(2043K) | References | Request Permissions Go bere for S5X

7. If THE ATLANTIC ROMAN TRADE DURING THE PRINCIPATE: NEW EVIDENCE FROM THE WESTERN FACCADE (pages 419-441) CESAR CARRERAS and RUI MORAIS

Anticle first published online: 9 OCT 2012 | DOt: 10.11110.1458-0092 2012.00395 3 Abstract | Full Article (HTML) | PDF(2511K) | References | Request Permissions Go here for SFX
Justifie Theck

WUISA FERRO and GUULO MAGL

Aticle first published online: 9 OCT 2012 | DOR 10.1111/6 1468-0092.2012.00395,

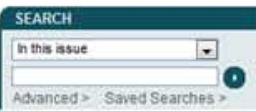

Online Open

Open Access

option for

your research

free to view

free to download

free to share

FIND OUT

\section{QWILE Job Network}

Wiay Science Jobs :

Search thousands of poss 00

Search thousands of plat
MORE O 


\title{
THE ASTRONOMICAL ORIENTATION OF THE URBAN PLAN OF ALEXANDRIA
}

\begin{abstract}
Summary. Alexander the Great founded Alexandria in 331 BC. An examination of the topography of the city today allows the identification of the essential elements of the original urban system, and shows that the site was chosen mainly for religious and symbolic reasons. In fact, Alexandria was the prototype of a series of Hellenistic towns designed as 'king's towns' that aimed to make explicit the divine power of their founder. We examine the orientation of the orthogonal grid, which was based on a main longitudinal axis, and show that this axis is orientated to the rising sun on the day of Alexander the Great's birth. At the time of foundation, 'King's Star' Regulus was also rising along the same direction.
\end{abstract}

\section{INTRODUCTION}

Alexander the Great founded Alexandria in 331 BC (Bagnall 1979). Alexandria can be viewed as the apex of several debates on the 'ideal town'. For instance, Plato repeatedly prefigures the birth of the ideal city (e.g. Laws IV-V). The inspiring principles are based on harmony as related to the laws and the divine, and reflected in the mathematical rigour of the design of the 'Hippodamian' city plan (Fig. 1) (Castagnoli 1971; Shipley 2005).

With Alexandria, the city becomes an explicit representation of the power of its divine founder, the rigorous order of its plan being a reflection of the 'cosmic' order, in compliance with the 'orthogonal grid' principles. The orthogonal grid of Alexandria can still be perceived, and it forms the basis for an ongoing project of reassessment of the antiquities and their integration into a coherent architectural scheme (Ferro and Pallini 2009; Torricelli 2010a; 2010b). The original matrix route was conceived on the basis of a longitudinal axis, later called the Canopic Road; the most important transverse axis was a dyke (Heptastadion) connecting the mainland with the Isle of Pharos. The Canopic Road played the role of an 'extended centre', a wide, longitudinal open space, with the main buildings distributed along it, thus avoiding the concept of a 'central point' as the focus of the urban plan (Fig. 2). The first to discern such a 'longitudinal' character in the original design of Alexandria was the nineteenth century astronomer Mahmoud-Bey Al-Falaki (Mahmoud-Bey 1861). Later excavations along the modern street revealed that the Canopic Road was deeply cut in the rock subsoil (Breccia 1914). The axis is thus an unusual feature, an icon in the foundation of the 


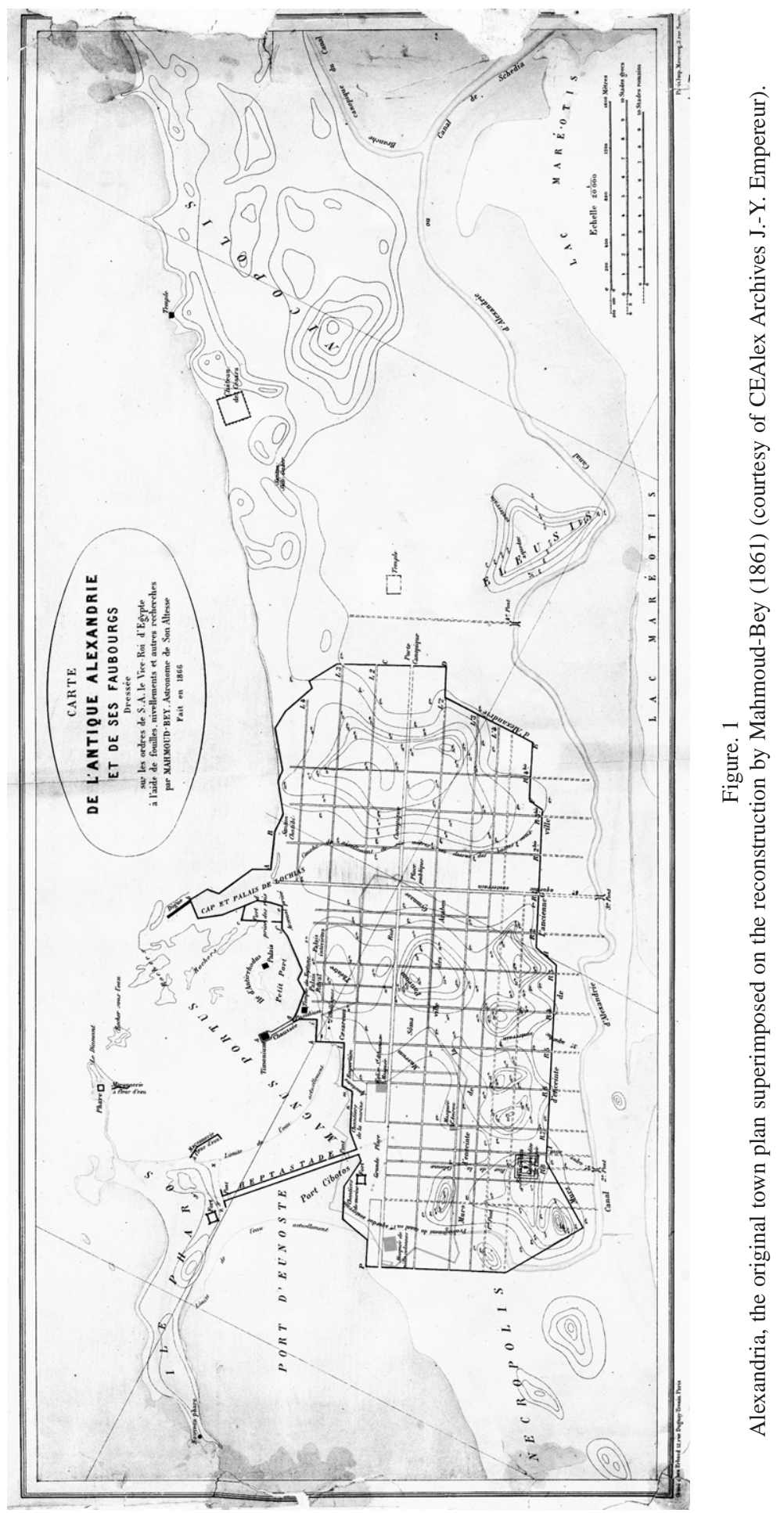




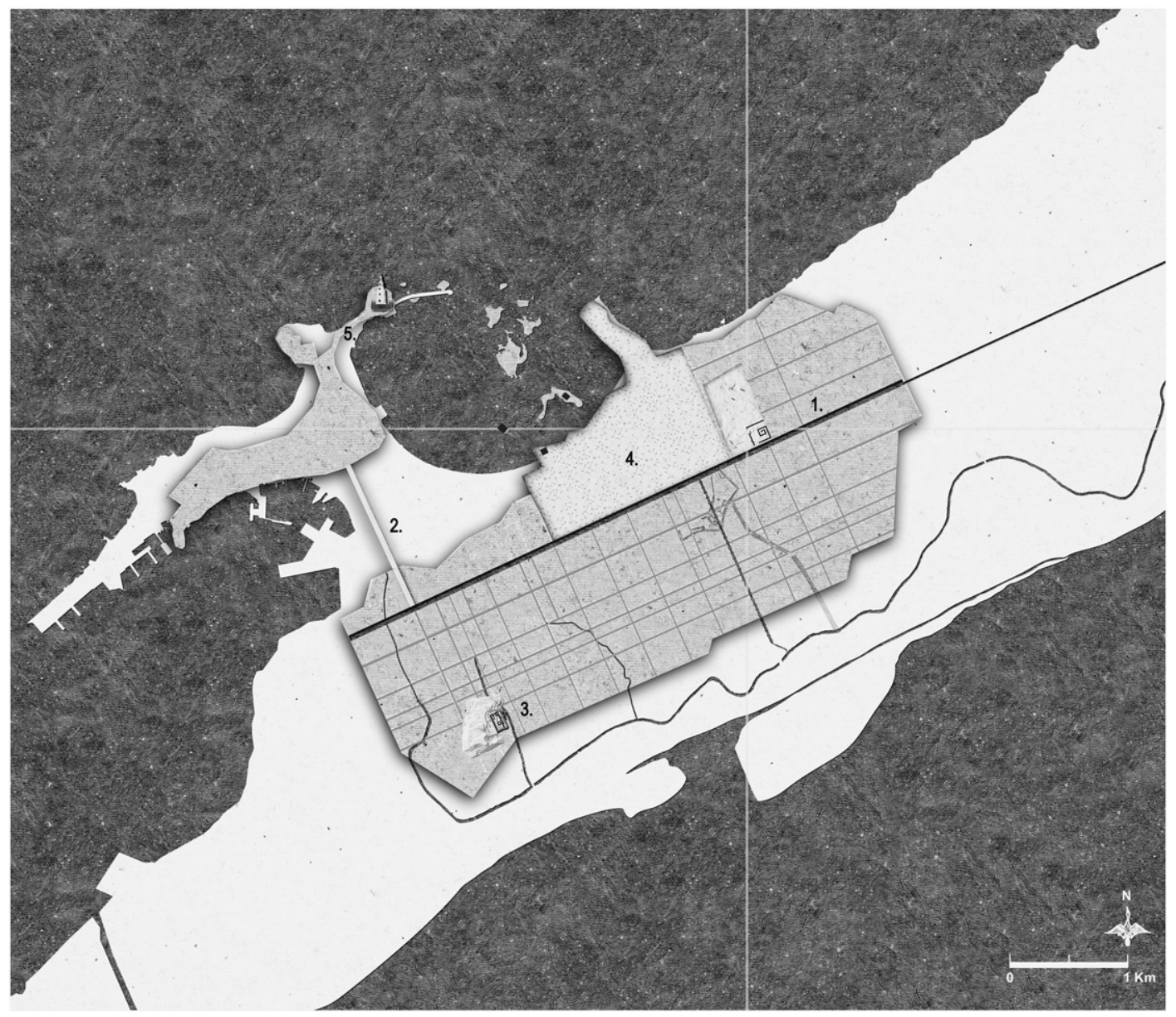

Figure. 2

Alexandria, reconstruction scheme of the original town plan. 1) Canopic Road; 2) Heptastadion; 3) Serapeum; 4) Imperial palace; 5) Isle of Pharos (@ Luisa Ferro).

city, and as such it forms an independent architectural unity (Fig. 3) (Mumford 1967; Caruso 1993; Ferro 2010a; 2010b). The same principle was later used in the town projects of the Seleucids (Wheeler 1968).

Despite the reports by Plutarch, in his Life of Alexander (26, 2-3), and by Diodorus Siculus $(17,52)$, the site where Alexandria was founded did not possess characteristics which made it especially suitable for settlement. In particular, the city was planned in a strip enclosed between the sea to the north and west, the marshy lands of the Canopic mouth of the Nile to the east, and Mareotis Lake to the south, in contrast to many of the criteria for a healthy location suggested by Alexander's tutor, Aristotle (Fig. 4) (Bernand 1995). Furthermore, a series of preliminary works was required before construction could begin: the Alexander Romance reports the existence of 12 channels which had to be drained in order to cover them with streets, and excavations have, in fact, shown the existence of at least three such channels. In addition, the 


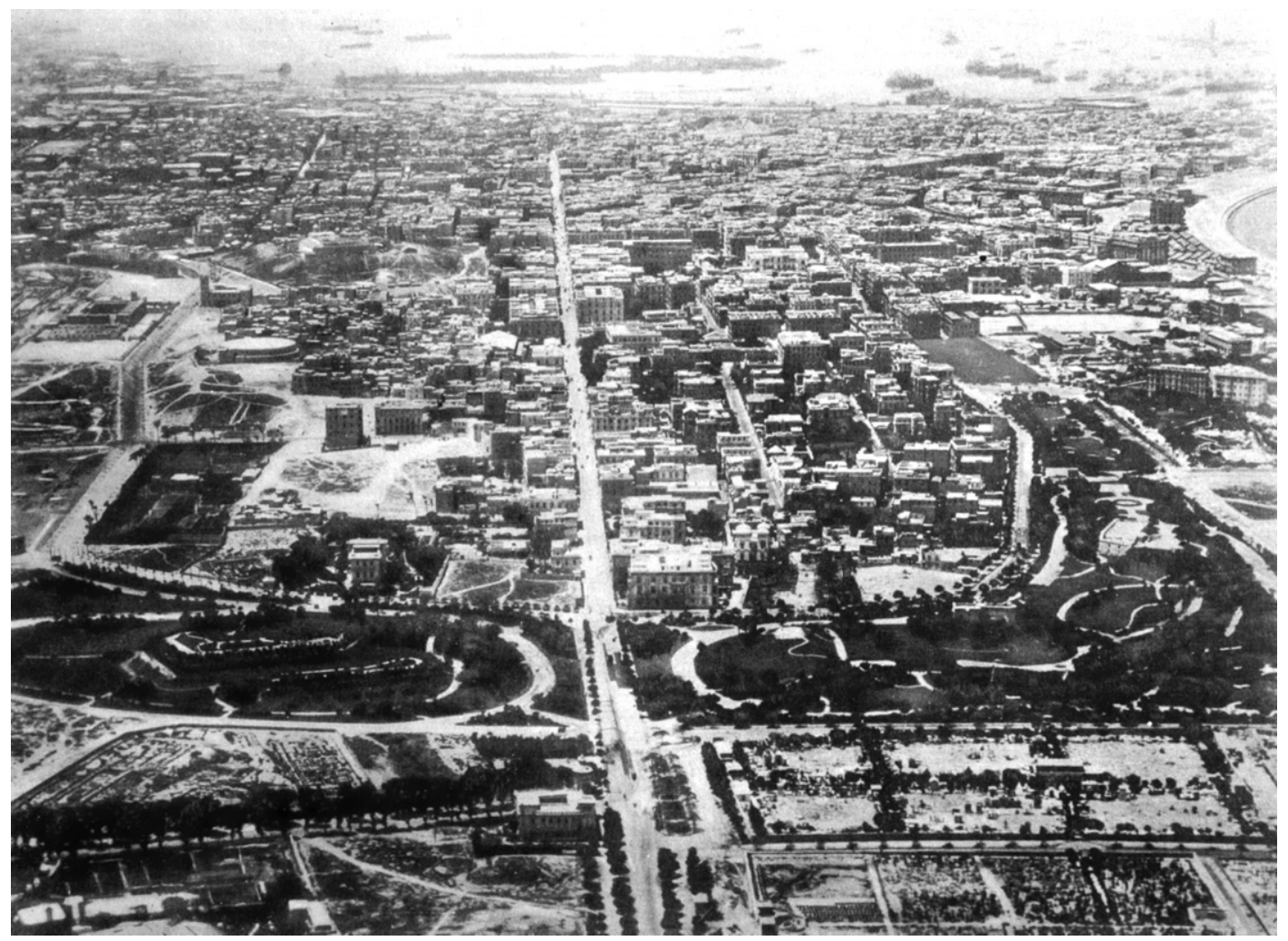

Figure. 3

A photograph of the early nineteenth century showing the Canopic Road, looking west (courtesy C. Pallini).

orientation of the orthogonal plan was not dictated by the topography, since the longitudinal axes are not parallel to the shoreline (the ancient shoreline of Alexandria was very similar to that of the present day: Goddio and Bernand 2005). In fact, when the Roman architects began constructing the Caesareum (probably founded by Cleopatra in honour of Mark Antony and later dedicated to Caesar Augustus), in order to place the front of the monument in clear view from the sea they were obliged to break the symmetry of the grid (McKenzie 2008).

We are therefore led to consider the foundation of Alexandria as a symbolic act, inspired by 'religious' criteria and with the aim of celebrating Alexander's power and divine nature (Ross Taylor 1927). Such a foundation was probably in compliance with the - already old - ritual: indeed the founders visited the oracle at Delphi before starting their enterprise. Alexander, however, visited the most important oracle in Egypt, the Ammon oracle at Siwa, probably just before the foundation (Bradford Welles 1962). The founder played the role of ancestor for the town as a whole, and was to be buried 'in the center of the city' (Detienne 1998) though the burial place of Alexander has not yet been found.

Among the possible symbolic aspects associated with foundation to be considered in any analysis of a town's design is, of course, orientation. In particular, it has been suggested on a number of occasions that several Roman towns, whose orientation does not conform to 


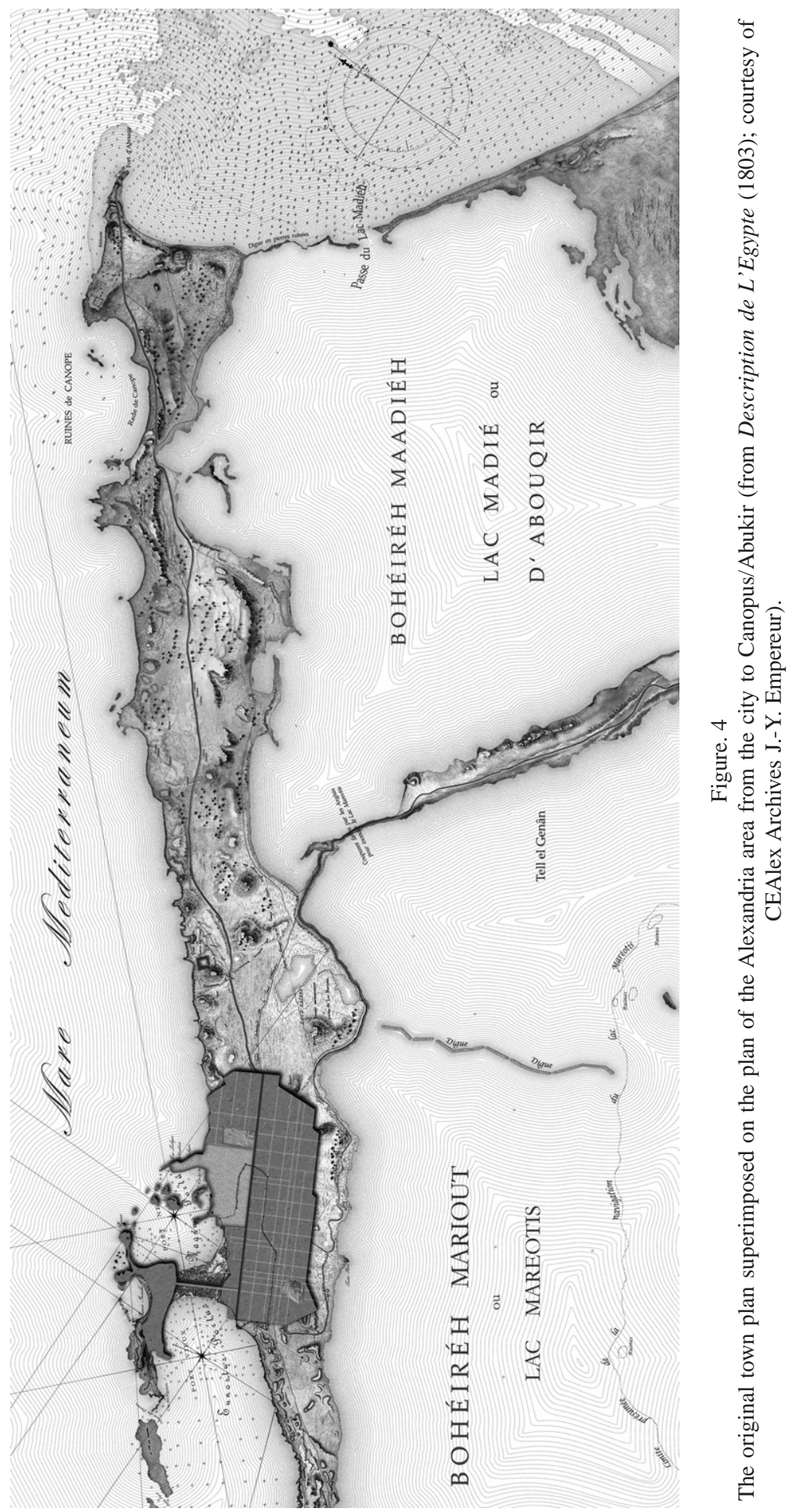


distinctive features in the landscape, were orientated in accordance with astronomical, rather than utilitarian, criteria. This has been recently investigated in a systematic way for Roman towns in Italy (Magli 2008). The present paper extends the investigation to Alexandria.

\section{ORIENTATION OF THE URBAN PLAN OF ALEXANDRIA}

As mentioned above, the rectangular grid of Alexandria was based on the so-called Canopic Road, which crossed the city and led to the Canopic mouth of the Nile and Canopus (today Abukir) Bay. At opposite ends of the street were located two main gates; since the work of Achilles Tatius (early second century AD) the east and west gates have been called Gate of the Sun and Gate of the Moon, respectively (Haas 1997). The Canopic Road bears an azimuth of $65^{\circ}$ $15^{\prime} \pm 30^{\prime} .{ }^{1}$ The horizon to the east extends towards Abukir Bay and was therefore flat in antiquity; the same is true of the west. It is possible that the only favourable point for the surveyors of the newly founded town was the 'hill' of the Serapeum, located to the south-west of the town, but even here the elevation is negligible (some $15 \mathrm{~m}$ ) so that the horizon on the sea can be considered as flat on both sides.

In $331 \mathrm{BC}$ the azimuth of the rising sun at the summer solstice was $62^{\circ} 20^{\prime}$ (today it is slightly displaced owing to the variation in the obliquity of the Ecliptic). It can be said, therefore, that the orientation of Alexandria on an axis of $65^{\circ} 15^{\prime}$ is 'solar' in that the sun was (and is) rising along this direction twice a year. The dates are 24 July and 2 June; the latter, in relation to the summer solstice, is the symmetric date. ${ }^{2}$ The range, $1^{\circ}$ wide and centred on azimuth $65^{\circ} 15^{\prime}$, was spanned by the rising sun over a period of a few days before and after this date, respectively. It is the aim of the present paper to defend the idea that this orientation was deliberate.

One could hypothesize a very rough solstitial alignment. However, the difference of some $3^{\circ}-$ and therefore an error of $3^{\circ}$ in determining the direction of the rising sun - looks excessive, both for the Egyptian and for the Greek standards of the period (Magli 2009). We propose here a quite different possibility, namely that the city was orientated to the rising sun on the day of Alexander the Great's birth. Alexander was born on $20 \mathrm{July,} 356 \mathrm{BC}$, and in the fourth century BC the sun was rising at Alexandria on that day at an azimuth of $64^{\circ} 30^{\prime}$, only $45^{\prime}$ less than our best estimate for the azimuth of the Canopic Road. The Julian date of birth of Alexander, however, has no connection with the calendar in use during that earlier period, and our proposal therefore requires careful consideration.

It is most probable that the calendar used by the planners of Alexandria was not the Egyptian solar ('civil') calendar of 365 days per year (this calendar lost around six days in relation to the sun cycle between 356 and $331 \mathrm{BC}$ ), but was, rather, the luni-solar Greek calendar (Hannah 2005). According to ancient sources such as Plutarch, Alexander was born

1 Because of the superposition of the modern town, it is not easy to calculate the orientation of the Alexandria grid with a precision better than $12^{\circ}$, which, however, is sufficient for the analysis presented here. To achieve such accuracy, we have compared several existing measurements with measurements obtained with a precision magnetic compass and corrected for magnetic declination.

2 The conventional calendar used in this paper, as is customary for dates BC, is the Proleptic Julian, obtained by extending the Julian count back in time. As the standard Julian calendar shifts backwards with respect to solar (Gregorian) dates AD, so the Proleptic Julian moves forward with respect to solar dates BC. Hence the date of 28 June for the solstice. 
on the sixth day of Hecatombaeon, the first month of the year. New Year's Day was the day of the first new moon after the summer solstice, and, in $356 \mathrm{BC}$, this occurred on 14 July, giving 20 July as the day of Alexander's birth. ${ }^{3}$ Owing to the length of the synodic month (about 29.53 days), however, the date of the new moon after the summer solstice varies from year to year, so that Hecatombaeon 6 moves through different solar dates as well. ${ }^{4}$ In other words, the date of Alexander's birth is not a fixed day in any solar calendar. It is, however, also true that Greek astronomers were perfectly able to trace the date of the new moon back in time. Indeed the Metonic cycle (stating that 19 tropical years are needed to complete 235 synodic months) had been known to them since the fifth century. The day of Alexander's birth was, together with the foundation of the city (Tybi 25, which fell on 7 April in $331 \mathrm{BC}$ ), the most important festivity of the town, celebrating Alexander as a living God. As with any festivity fixed according to the moon (e.g. Christian Easter), the date varied from year to year, as did many other pre-existing festivities in the Greek world. Owing to the fluctuation of the lunar calendars and to differences between local calendars, the Greeks employed astronomical methods to act as harbingers for relevant festivities (Hannah 2005; 2009; Salt and Boutsikas 2005). In this respect, the alignment to the rising sun in the companion solar date might have been used as a solstitial marker - and therefore as a 'correct new moon indicator' - occurring a number of days (26), close to a lunar month, before the summer solstice. In addition, the heliacal rising of stars was used as a harbinger of important festivals, and the Alexandria alignment also functioned in this sense. Surprisingly, the star associated with kingship since Babylonian times, 'King's Star' Regulus (alpha-Leonis), was at that time rising at the same azimuth $\left(65^{\circ} 20^{\prime}\right.$ at an altitude of $1^{\circ}$, appropriate for the visibility of a first magnitude star) and had a heliacal rising very near to 20 July (the precise date of the heliacal rising of a star depends on many factors and cannot be precisely defined; see Schaefer 1986).

\section{CONCLUSIONS}

When a deliberate astronomical alignment is proposed, it is of course essential to investigate the possibility of a mere coincidence. If the sample under examination is large enough, a statistical analysis can be applied to evaluate the probability of casual alignments (Ruggles 2005; Magli 2008). Alexandria has no precedent among previously founded Greek towns but a comparative analysis can be made of other towns founded by Alexander and those founded later by the Seleucids, as will be demonstrated elsewhere. Here, we mention only that the same date as at Alexandria is alluded to in the orientation of Seleucia on the Tigris, the capital founded in 300 BC by Seleucus I Nikator not far from Babylon (Ferro and Magli in prep.). Further, Belmonte and García (2010) have independently found the same alignment in the funerary monument of Antiochos I, king of Commagene, at Mount Nemrud. The coincidence with Alexandria is striking, considering that Antiochos makes explicit reference in the inscriptions on the monument to Alexander the Great as an ancestor.

3 This calculation has been made by several authors; we have independently checked it as well. All astronomical data in the present paper have been produced using the software @ StarryNight Pro 6.0.

4 In $331 \mathrm{BC}$ the first new moon after the summer solstice occurred on 9 July, thus giving 14 July for Hecatombaeon 6. This day corresponds to the sun rising about halfway between the summer solstice and the orientation of the grid. 
These examples hint at the existence of a traditional pattern of orientation first established in Alexandria. Alexander the Great confirms himself, once again, as a 'major turning point in history', as Sir Mortimer Wheeler (1968) once said.

\section{Acknowledgements}

The present work arises from a more extensive research project (entitled Archaeology and Architecture) devoted to the enhancement of the Archaeological Areas of Alexandria, co-coordinated by Angelo Torricelli, whose constant help and encouragement is gratefully acknowledged. The project includes collaboration with the University of Torino, the Alexandria and Mediterranean Research Center, the Department of Architecture of Menofeya University, and the Italian Archaeological Mission at Alexandria coordinated by Paolo Gallo. The current project mission entitled 'Kosa Pasha Fort, Abuqir' is operating under an International Protocol of scientific collaboration with the Supreme Council of Antiquities (SCA) of Egypt. Architects Viola Bertini and Elena Ciapparelli, who have worked on images, and students Marina Bianconi and Valentina Sala are also gratefully acknowledged.

Faculty of Civil Architecture Politecnico di Milano ITALY

E-mail: luisa.ferro@polimi.it giulio.magli@polimi.it

\section{REFERENCES}

Bagnall, R.S. 1979: The date of the foundation of Alexandria. American Journal of Ancient History 4, $46-9$.

Belmonte, J.A. and García, C.G. 2010: Antiochos' hierothesion at Nemrud Dag revisited: adjusting the date in the light of astronomical evidence. JHA 41, 469-81.

BERNAND, A. 1995: Alexandrie des Ptolomées (Paris, CNRS Editions).

BRADFORD WELlES, C. 1962: The discovery of Sarapis and the foundation of Alexandria. Historia: Zeitschrift für Alte Geschichte 11(3), 271-98.

BRECCIA, E. 1914: Alexandrea ad Aegyptum. Guide de la Ville ancienne et moderne et du Musée GrécoRomain (Bergamo, Istituto Italiano d'arti grafiche).

CARUSO, G. 1993: Alcuni aspetti dell'urbanistica di Alessandria in età ellenistica: il piano di progettazione. In Alessandria e il mondo ellenistico-romano. Studi in onore di Achille Adriani, Vol. 4 (Roma), 43-53.

Castagnoli, F. 1971: Orthogonal Town Planning in Antiquity (Cambridge, MA).

DETIENne, M. 1998: Apollon le couteau à la main. Une approche expérimentale du polythéisme grec (Paris).

FERRO, L. 2010a: Archeologia e progetto di architettura. In Vazzana, S. and Romagnoli, C. (eds.), Riprogettare l'archeologia (Milano, RotarArch), 35-8.

FERRO, L. 2010b: Alessandria d'Egitto. Un progetto per la città. Ananke 61, 117-25.

FERro, L. and MAGLI, G. in prep.: The Role of Astronomy in the Planning of Hellenistic Towns.

FERro, L. and PALlini, C. (eds.) 2009: Alessandria d'Egitto oltre il mito. Alexandria Beyond the Myth. Architecture, Archaeology, Urban Change (Boves-Cuneo).

GODDIO, F. and BERNAND, A. 2005: Sunken Egypt-Alexandria (London).

HAAS, C. 1997: Alexandria in Late Antiquity: Topography and Social Conflict (Baltimore).

HANNAH, R. 2005: Greek and Roman Calendars: Constructions of Time in the Classical World (London). HANNAH, R. 2009: Time in Antiquity (London).

MAGLI, G. 2008: On the orientation of Roman towns in Italy. Oxford Journal of Archaeology 27(1), 63-71. MAGLI, G. 2009: Mysteries and Discoveries of Archaeoastronomy (New York). 
MAHMOUD-BEy, ASTRONOME DE S.A. 1861: Mémoire sur l'antique Alexandrie, ses faubourgs et environs découvertes, par les fouilles, sondages, nivellements et autres recheches (Copenhagen).

MCKENZIE, J. 2008: The Architecture of Alexandria and Egypt 300 BC-AD 700 (New Haven and London). MUMFORD, L. 1967: The City in History (Milano).

ROSS TAYlor, L. 1927: The cult of Alexander at Alexandria. Classical Philology 22, 62-169.

RUGGLES, C.L.N. 2005: Ancient Astronomy: An Encyclopedia of Cosmologies and Myth (London).

SAlt, A. and BoutsiKas, E. 2005: Knowing when to consult the oracle at Delphi. Antiquity 79, 564-72.

SCHAEFER, B. 1986: Atmospheric extinction effects on stellar alignments. Archaeoastronomy 10, 32-42.

SHIPLEY, G. 2005: Little boxes on the hillside: Greek town planning, Hippodamos, and polis ideology. In

Hansen, M.H. (ed.), The Imaginary Polis: Symposium (Copenhagen, Historisk-filosofiske meddelelser, 91; Acts of the Copenhagen Polis Centre, 7), 335-403.

TORRICELLI, A. 2010a: Aree archeologiche e progetto per le città. Ananke 61, 110-15.

TORRICELLI, A. 2010b: La ricerca progettuale come interrogazione del tempo. In Riprogettare l'archeologia (Milano, RotarArch), 11-14.

WHEELER, M. 1968: Flames over Persepolis. Turning-point in History (London). 